\title{
ESTIMATION OF HEAT SHOCK PROTEIN 70 (Hsp 70) GENE EXPRESSION IN NILE TILAPIA (Oreochromis niloticus) USING QUANTITATIVE REAL- TIME PCR
}

\author{
Ahmed H.A.M. El-Sappah ${ }^{*}$, A.S.H. Shawky, Mahassen S. Sayed-Ahmad and M.A.H. Youssef \\ Genet. Dept., Fac. Agric., Zagazig Univ., Egypt
}

Received: 07/03/2017 ; Accepted: 30/04/2017

\begin{abstract}
Heat shock protein 70 (Hsp70) is one of family of proteins expressed in response to a wide range of biotic and abiotic stress conditions. Quantitative real-time PCR (qRT-PCR) has been used to study the expression profiles of heat shock protein (Hsp70) gene in Nile tilapia, Oreochromis niloticus. Young fish $(30 \mathrm{~g})$ were exposed to different degrees of heat $(10,15,35,39)$ and control $\left(28^{\circ} \mathrm{C}\right)$ for 2 and $4 \mathrm{hr}$., followed by qRT-PCR of Hsp70 mRNA, using Beta actin (B-Actin) as a reference gene and flourogenic dyes. Expression of Hsp70 gene was different among fish tissues (muscles, gills and liver). In all treatments the expression level detected in male were more than female fish. The highest expression organs after $2 \mathrm{hr}$., was muscles in both fish sex but after $4 \mathrm{hr}$., liver recorded the highest expression value at cold shock where muscles recorded the highest expression at heat shock treatments in both fish sex.
\end{abstract}

Key words: Nile tilapia, Oreochromis niloticus, Heat shock proteins , Hsp70, Real- time PCR.

\section{INTRODUCTION}

By exposure to high temperature, cells will mount a strong physiological response, including the heat stress response and the expression of heat shock proteins (Hsps). Hsps and the associated stress response have been shown to be induced by cold and a range of other stresses including insecticides, heavy metals, desiccation, diseases, parasites, inbreeding and habitat condition (Sørensen et al., 2003 ; Herring et al., 2009). Thus, the heat stress response is considered to be a fundamental component of the physiological response to stress. Hsps play a pivotal role in protein homeostasis and cellular stress response within the cell (Iwama et al., 1998; Feder and Hofmann, 1999; Multhoff, 2007; Keller et al., 2008). Disruption of normal cellular processes may cause rapid increase in the synthesis of a group of proteins which belong to the Hsp families. These proteins have been classified into several families based on their molecular weight such as Hsp 90 (85-90

* Corresponding author: Tel. : +201122988925

E-mail address: ahmed_elsappah2006@yahoo.com
kDa), Hsp70 (68-73 kDa), Hsp 60, Hsp 47, and small Hsps (12-43 kDa) (Hallare et al., 2004; Park et al., 2007). The Hsp genes are highly conserved and have been characterized in a wide range of organisms. The heat shock response is an evolutionarily conserved mechanism for maintaining cellular homeostasis following sub lethal noxious stimuli (Lindquist, 1986; Lindquist and Craig, 1988).

Like all Hsps family, Hsp70 has been recognized as a molecular chaperone, playing a central role in cell biology and biochemistry (Bukau and Horwich, 1998; Iwama et al., 1998; Mayer and Bukau, 1998). Hsp70 and its co-chaperones, encoded by multi- gene family members, are developmentally regulated and differentially expressed in response to temperature stress and also, to other conditions that interrupt normal protein folding or favour protein denaturation (Schelesinger, 1990 ; Sanders, 1993). Many Hsp 70 genes are strongly and rapidly induced at $37-45^{\circ} \mathrm{C}$ within a period of $30 \mathrm{~min}$. to $2 \mathrm{hr}$., (Liu and Saint, 2002). Under adverse environmental conditions, the 
new synthesis of stress Hsp70 increases, and it takes on new but related role to protect the cell from other adverse effect. (Basu et al., 2002), described the functions of Hsp70 in various aspects of fish physiology, including development and aging, stress physiology, endocrinology, immunology, environmental physiology, acclimation then with stress tolerance. Molina et al. (2000) reported that Hsp70 in tilapia, Oreochromis mossambicus promoter is able to confer the heat shock response on a reporter gene after transient expression, both in cell culture and in microinjection process. The most widely studied member of the Hsp families, especially in response to proteotoxic is the 70 $\mathrm{kDa}$ (Hsp70) family of proteins (Feng et al., 2003 ; Luciana et al., 2006). Basu et al. (2003) reported that a physiological response as well as an inducible cellular stress response occurs in Hsp70 family. It is only this specie that is subjected to these stressful conditions, for this has not been observed in the cellular and tissues- responses of other teleosts species.

Fish are an excellent vertebrate model to investigate the physiology, function and regulation of Hsps, because they are exposed to thermal and other stressors in their nature environment. The relationship between Hsp synthesis and the development of thermo tolerance has been studied by some investigators (Mosser et al., 1987; Chen et al., 1988). The effects of daily and seasonal temperature fluctuations as well as acclimation temperature have also been examined, especially in fish species (Koban et al., 1987 ; White et al., 1994).

Tilapias are a group of fish belong to order Teleostei and family Cichlidae. Tilapias are divided into three main genera; Oreochromis, Tilapia and Sarotherodon, (Trewavas, 1983). There are four tilapia species in Egypt; Nile tilapia (Oreochromis niloticus), blue tilapia (Oreochromis aureus), white tilapia (Sarotherodon galilaeus) and green tilapia (Tilapia zillii). The diploid chromosome number of these species is 44 (Ergene and Cavas, 1999). Nile tilapia (Oreochromis niloticus) is the most commercially important freshwater fish in Egypt due to their relatively fast growth rate and consumer preference. The major part of the Egyptian fish production (capture and aquaculture) is coming from tilapia fish production.
Quantitative real time polymerase chain reaction (qRT-PCR) is a variant of polymerase chain reaction (PCR), a laboratory technique commonly used in molecular biology to generate many copies of a DNA sequence and a flourogenic dye, which is used to continuously monitor product accumulation. With this methods, the initial concentration of template DNA is assessed by using the number of PCR amplification that enters the exponential phase. Other methods such as northern hybridization, RNase protection assay and in situ hybridization have been used for quantification of gene expression. However, qRT-PCR has many advantages over these methods, including analysis time and sensitivity, specificity, case of use and reproducibility (Freeman et al., 1999; Klein, 2002; Liu and Saint, 2002 ; Radonic et al., 2004).

The aim of this work was to study the expression profile of heat shock protein 70 across different sex and organs of Nile tilapia (Oreochromis niloticus).

\section{MATERIALS AND METHODS}

This study was carried out at summer months in Molecular Genetics Lab, cytogenetics Lab and Microbial genetic Lab in Genetics Dept., Fac. Agric. and Unit of Biotechnology, Faculty of Veterinary Medicine in Zagazig Univ., Egypt.

\section{Fish Sampling}

Nile tilapia (Oreochromas niloticas) male and female were grown in laboratory tanks that have water of constant temperature $\left(28^{\circ} \mathrm{C}\right)$ all have approximately weight $30 \mathrm{~g}$. Fish were fed once daily on tilapia grown diet.

\section{Heat Shock Exposure}

Sixteen fish were acclimatization for more than $72 \mathrm{hr}$., at normal temperature $\left(28^{\circ} \mathrm{C}\right)$ then fish were moved to similar tank where the water was in wanted heat treatments $(10,15,35$ and $39^{\circ} \mathrm{C}$ ) and were left in all treatments once for two hours and in other one for four hours. Then the fish were moved back to the tank of normal temperature and were left for two more hours. Fish were dissected to obtain gills, liver and muscles. These body tissues were kept directly with dry ice and then kept in more $-20^{\circ} \mathrm{C}$ for further use. 


\section{RNA Extraction}

Total RNA was isolated from $2 \mathrm{~g}$ of each of the samples of frozen liver, kidney, gills and intestine according to the Standard Acid Guanidinium Thiocyante Phenol Chloroform (AGPC) extraction method (Chomczynski and Sacchi, 1987). Total RNA concentration and purity were determined spectrophotometrically as described by Sambrook and Green (2002) or the reaction products were analyzed by electrophoresis on $1.4 \%$ agarose gels stained with ethidium bromide and photographed under UV light.

\section{Reverse Transcription}

Reverse transcription (RT) was performed using Primescript TM RT reagent kit (Takara, Japan) according to the manufacturer's instructions. $5 \mu \mathrm{l}$ of $10 \mathrm{X}$ Buffer RT (GENI, Bangalore), $2 \mu \mathrm{l}$ of dNTPs ( $5 \mathrm{mM}$ each), $0.5 \mu \mathrm{l}$ Oligo-dt $(10 \mu \mathrm{M}), 0.25 \mu 1$ RNAse inhibitor (10 $\mathrm{U} / \mu \mathrm{l}), 1 \mu 1$ sensiscript Reverse Transcriptase and RNAse - free water up to $20 \mu \mathrm{L}$ were added to $50 \mathrm{ng}$ of RNA. The mixed solution was allowed to vortex for $5 \mathrm{~min}$ after incubating at $37^{\circ} \mathrm{C}$ for $15 \mathrm{~min}$ then $5 \mathrm{~s}$ at $85^{\circ} \mathrm{C}$ to inactivate the reverse transcriptase. RT products were stored at $4^{\circ} \mathrm{C}$ for further PCR analysis.

\section{Primers for RT-PCR}

Primers were designed with the help of primer 3 program (http: frodo.wi.mit.edu/cgibin/primer3/ primer 3-www.cgi). Specific PCR primers for the HSP70 protein corresponding gene (283bp) were designed A sense strand primer was 5'-GCATTCACACCATGAGGC GTT-3' and antisense primer 5'-GCTTTGACA CGCTTCCCATT-3' with annealing temperature $59^{\circ} \mathrm{C}$. Then second degenerate primers for $\mathrm{B}-$ Actin (ACTIN) gene (143 bp) were designed A sense strand of Forward: 5'-CTACAATGAGC TGCGTGTGG-3' and anti sense 5'-AAGGAA GGCTGGAAGAGTGC-3' with annealing temperature $58.5^{\circ} \mathrm{C}$ B-Actin sequences, ESTs found on the internet databases: EBI (http:// www.sbi.ac.uk/ Databases/) and NCBI (http:// www.ncbi.nlm.nih.gov/).

\section{qRT-PCR Condition and Analysis}

Each PCR reaction consisted of $10 \mu 1$ of SYBR Premix Ex Taq (2X), $0.5 \mu 1$ of each primer $(10 \mu \mathrm{M}), 2 \mu \mathrm{l}$ of cDNA template $(500$ $\mathrm{ng} / \mu \mathrm{l})$ and double distilled water to a final volume of $20 \mu \mathrm{l}$. Reactions were then analyzed on an the Rotor- Gene Q system under the following conditions: $95 \mathrm{C}$ for $10 \mathrm{~s}$ and 40 cycles of $95^{\circ} \mathrm{C}$ for $5 \mathrm{sec}$., followed by $60 \mathrm{C}$ for 1 min. All standard dilutions, no template controls, and induced samples were run in triplicates. The fluorescence signals were measured at the end of each extension step. The threshold cycle $(\mathrm{Ct})$ was determined for each sample using the exponential growth phase and the baseline signal from the fluorescence versus cycle number plots. To ensure that a single product was amplified, melt curve analysis was performed on the PCR products at the end of each PCR run, then normalizes the $\mathrm{Ct}$ data using single or multiple endogenous control genes (Livak and Schmittgen, 2001 ; Schmittgen and Livak, 2008):

$\Delta \mathrm{Ct}=\mathrm{Ct}$ gene of interest-Normalization factor (1)

Normalization Factor is the arithmetic mean or geometric mean of $\mathrm{Ct}$ values of the selected control genes. If multiple genes are selected as controls, a gene stability measure is also calculated based on the geNorm

Algorithm to assist with selecting most stable control genes for data normalization. The normalized $\Delta \mathrm{Ct}$ data are used to calculate the relative gene expression fold change using a selected calibrator (reference sample):

$\Delta \Delta \mathrm{Ct}=\Delta \mathrm{Ct}$ sample $\mathrm{A}-\Delta \mathrm{Ct}$ calibrator

Fold Change $=2-\Delta \Delta \mathrm{Ct}$

The fold change can also be calculated between sample groups of biological replicates, by grouping samples to biological replicates, the mean $2-\Delta \mathrm{Ct}$ of the biological replicates is used to determine the expression fold change :

Fold Change $=2-\Delta \mathrm{C}$ tgroup $\mathrm{A} / 2-\Delta \mathrm{Ct}$ reference (4)

\section{RESULTS AND DISCUSSION}

Nile tilapia (Oreochromis niloticus) known to tolerate high temperatures, it can not tolerate for a long period water temperature between 10 and $15^{\circ} \mathrm{C}$ (Ballarine and Hatton, 1979), and does not survive below $10^{\circ} \mathrm{C}$ (Chervinski and Lahav, 1976). The optimum temperature for feeding, 
growth and reproduction is between 22 and $30^{\circ} \mathrm{C}$ (Caulton, 1982) while good growth was recorded in upper portion of this range (Hauser, 1977). Thus, at high or low temperatures, feeding and growth rates are reduced, and at $20^{\circ} \mathrm{C}$ or less, feeding and growth are stopped (Caulton, 1982). In this study the expression of Hsp70 gene was estimated under several thermal treatments vary between cold and high temperatures on both sex (males and females) of tilapia. These temperatures were $39,35,15$, 10 and control $28^{\circ} \mathrm{C}$. These treatments had been done on two experiments; the first one was two hours exposing treatment and the second one was four hours and both followed by one hour recovery at $28^{\circ} \mathrm{C}$. After both experiments fish have been dissected and obtained the three tissues for study (muscles, liver and gills, Fig. 1) to estimate Hsp70 expression in this organs where RNA isolated and confirmed by gel electrophoresis which showed a quantitative differences between bands intensity (Fig. 2) followed by reverse transcriptase into cDNA which did not show a quantitative difference between bands inttensity (Fig. 3). Real-time PCR using specific primers for Hsp70 and Bactin with Sypergreen for these samples were obtains (Fig. 4) this is a good proof that gene have been expressed, this agreed with that of Indhuleka and Jeyanthi (2011) whom reported that gel electrophoresis of Rt-PCR products reflect the success of Rt-PCR experiment, then the results showed on computer (Fig. 5) which represented the values of cycle threshold $(\mathrm{Ct})$ and from $\mathrm{Ct}$ values and by some equations gene expression had been calculated (Tables 1 and 2). The results after 2 hours treatment (Table 1 and Fig. 6) showed that the most Hsp70 expression tissue in both fish sex was muscles followed by gills and liver and the highest expression level of Hsp70 in tissues was found at $10^{\circ} \mathrm{C}$ followed by $39^{\circ} \mathrm{C}$ then $15^{\circ} \mathrm{C}$ and $35^{\circ} \mathrm{C}$ treatment. The highest expression at $10^{\circ} \mathrm{C}$ in males tissues (muscles, liver and gills) recorded (17.39, 15.45 and 12.47 folds up regulation, respectively) and in females was $(16.22,12.99$ and 7.94 folds up regulation, respectively) but the lowest expression at $35^{\circ} \mathrm{C}$ in males recorded $(1.35$ up regulation but 0.2 and 0.67 folds down regulation, respectively) and in females was (1.16 up regulation but 0.18 and 0.29 folds down regulation, respectively). These results do agree with Sharaf El-Deen (2006) who found that in Nile tilapia after sudden heat of $34^{\circ} \mathrm{C}$ for $2 \mathrm{hrs}$, the accumulation of $\mathrm{Hsp} 70$ was 2 to 3 -folds greater than in control fish, in the different examined tissues and spleen was recorded as the most sensitive organ where it had the highest response of Hsp70 accumulation. Gills were the second specific tissue target of heat shock, then heart and lastly the liver tissue (liver, may be prior to its normal high growth temperature). The expression of Hsp70 at cold shock were more than heat shock, this might due to the cold shock in summer affected on fish more than heat shock because the large different between the temperature of shock and room temperature and this reason agree with Nagy (1987), who reported that cold shock is effective primarily on warm water fish and heat shock on cold water one. Other reason that fish can avoid localization stressful temperature so heat shock is less likely to kill fish than cold shock (Langford, 1983). On the other hand, the results after 4 hours treatment showed that, males were different from females in Hsp70 induction, where the expression values in males was higher than females (Table 2 and Fig. 7), and the values of expression were varied between all thermal treatments, where $10^{\circ} \mathrm{C}$ showed the highest expression of Hsp 70 followed by $39^{\circ} \mathrm{C}$ then $15^{\circ} \mathrm{C}$ and $35^{\circ} \mathrm{C}$ treatment. In cold shock $\left(15^{\circ} \mathrm{C}\right.$ and $10^{\circ} \mathrm{C}$ ), the highest expression level of Hsp70 was found in liver followed by muscles and gills in both fish sex. The highest expression value was found in liver at $10^{\circ} \mathrm{C}$ in males (32.22 folds) and females (24.59 folds) as up regulation but the lowest expression value found in gills at $35^{\circ} \mathrm{C}$ recorded in males ( 2.3 folds) and females (1.61 folds). These results do agree with Gui-Cheng et al. (2015) where they found that the expression of liver Hsp70 at cold shock was more than in muscles tissues and the Hsp70 in liver of tilapia fish showed more volatility during cold stress compared with that in muscles. A possible explanation is that liver as a metabolic organ of fish, is more susceptible than muscle in response to environmental stressors such as cold stress. However, a country finding revealed that Hsp70 level in muscle elevated higher than hepatic tissues in tilapia under hypoxia condition (Delaney and Klesius 2004). 
Zagazig J. Agric. Res., Vol. 44 No. (3) 2017

Table 1. Amount of Hsp70 mRNA, normalized to $\mathbf{B}$-Actin mRNA in $2 \mathrm{hr}$., treatment

\begin{tabular}{|c|c|c|c|c|c|c|c|}
\hline Treatment & Sex & Sample name & $\begin{array}{l}\text { Hsp70 gene } \\
\text { average } \mathrm{Ct}\end{array}$ & $\begin{array}{c}\text { Tilapia } \boldsymbol{B} \text {-Actin } \\
\text { average } \mathrm{Ct}\end{array}$ & $\Delta \mathbf{C t}$ & $\Delta \Delta \mathbf{C t}$ & ${ }_{2-\Delta \Delta \mathbf{C t}}$ \\
\hline \multirow{6}{*}{$\begin{array}{l}28^{\circ} \mathrm{C} \\
\text { (control) }\end{array}$} & \multirow{3}{*}{ Male } & Muscle & 20.44 & 16.20 & 4.24 & 0 & 1 \\
\hline & & Liver & 22.30 & 18.61 & 3.69 & 0 & 1 \\
\hline & & Gill & 17.50 & 20.06 & -2.56 & 0 & 1 \\
\hline & \multirow{3}{*}{ Female } & Muscle & 23.20 & 18.01 & 5.19 & 0 & 1 \\
\hline & & Liver & 25.46 & 19.32 & 6.14 & 0 & 1 \\
\hline & & Gill & 24.20 & 26.03 & -1.83 & 0 & 1 \\
\hline \multirow{6}{*}{$39^{\circ} \mathrm{C}$} & \multirow{3}{*}{ Male } & Muscle & 22.22 & 22.58 & -0.36 & -2.84 & 7.16 \\
\hline & & Liver & 19.28 & 19.02 & 0.26 & -2.22 & 4.66 \\
\hline & & Gill & 20.80 & 21.04 & -0.24 & -2.72 & 6.59 \\
\hline & \multirow{3}{*}{ Female } & Muscle & 21.22 & 21.50 & -0.28 & -2.76 & 6.77 \\
\hline & & Liver & 17.47 & 17.00 & 0.47 & -2.01 & 4.02 \\
\hline & & Gill & 20.74 & 20.50 & 0.24 & -2.24 & 4.72 \\
\hline \multirow{6}{*}{$35^{\circ} \mathrm{C}$} & \multirow{3}{*}{ Male } & Muscle & 21.40 & 19.35 & 2.05 & -0.43 & 1.35 \\
\hline & & Liver & 22.04 & 17.22 & 4.82 & 2.34 & 0.1975 \\
\hline & & Gill & 31.67 & 28.61 & 3.06 & 0.58 & 0.67 \\
\hline & \multirow{3}{*}{ Female } & Muscle & 20.43 & 18.16 & 2.27 & -0.21 & 1.16 \\
\hline & & Liver & 24.23 & 19.25 & 4.98 & 2.50 & 0.1767 \\
\hline & & Gill & 33.28 & 29.02 & 4.26 & -1.78 & 0.29 \\
\hline \multirow{6}{*}{$15^{\circ} \mathrm{C}$} & \multirow{3}{*}{ Male } & Muscle & 17.98 & 17.47 & 0.51 & -1.97 & 3.92 \\
\hline & & Liver & 19.66 & 18.64 & 1.02 & -1.46 & 2.75 \\
\hline & & Gill & 19.28 & 18.14 & 1.14 & -1.34 & 2.53 \\
\hline & \multirow{3}{*}{ Female } & Muscle & 19.67 & 18.84 & 0.83 & -1.65 & 3.14 \\
\hline & & Liver & 18.22 & 17.12 & 1.10 & -1.38 & 2.60 \\
\hline & & Gill & 21.61 & 20.07 & 1.54 & -0.94 & 1.92 \\
\hline \multirow{6}{*}{$10^{\circ} \mathrm{C}$} & \multirow{3}{*}{ Male } & Muscle & 25.46 & 27.10 & -1.64 & -4.12 & 17.39 \\
\hline & & Liver & 20.20 & 21.67 & -1.47 & -3.95 & 15.45 \\
\hline & & Gill & 21.40 & 22.56 & -1.16 & -3.64 & 12.47 \\
\hline & \multirow{3}{*}{ Female } & Muscle & 23.52 & 25.06 & -1.54 & -4.02 & 16.22 \\
\hline & & Liver & 22.03 & 23.25 & -1.22 & -3.70 & 12.99 \\
\hline & & Gill & 20.01 & 20.52 & -0.51 & -2.99 & 7.94 \\
\hline
\end{tabular}

$\overline{\text { Mean of } \Delta \mathrm{Ct} \text { of control }}=2.48 \quad \mathrm{Ct}=\overline{\text { Cycle threshold }}$.

$\Delta \mathrm{Ct}=\mathrm{Ct}$ gene of interest-normalization factor. $\Delta \Delta \mathrm{Ct}=\Delta \mathrm{Ct}$ sample $\mathrm{A}-\Delta \mathrm{Ct}$ calibrator ${ }_{2}-\Delta \Delta \mathrm{Ct}=$ Gene expression. 
Table 2. Amount of Hsp70 mRNA, normalized to B-Actin mRNA in $4 \mathrm{hr}$., treatment

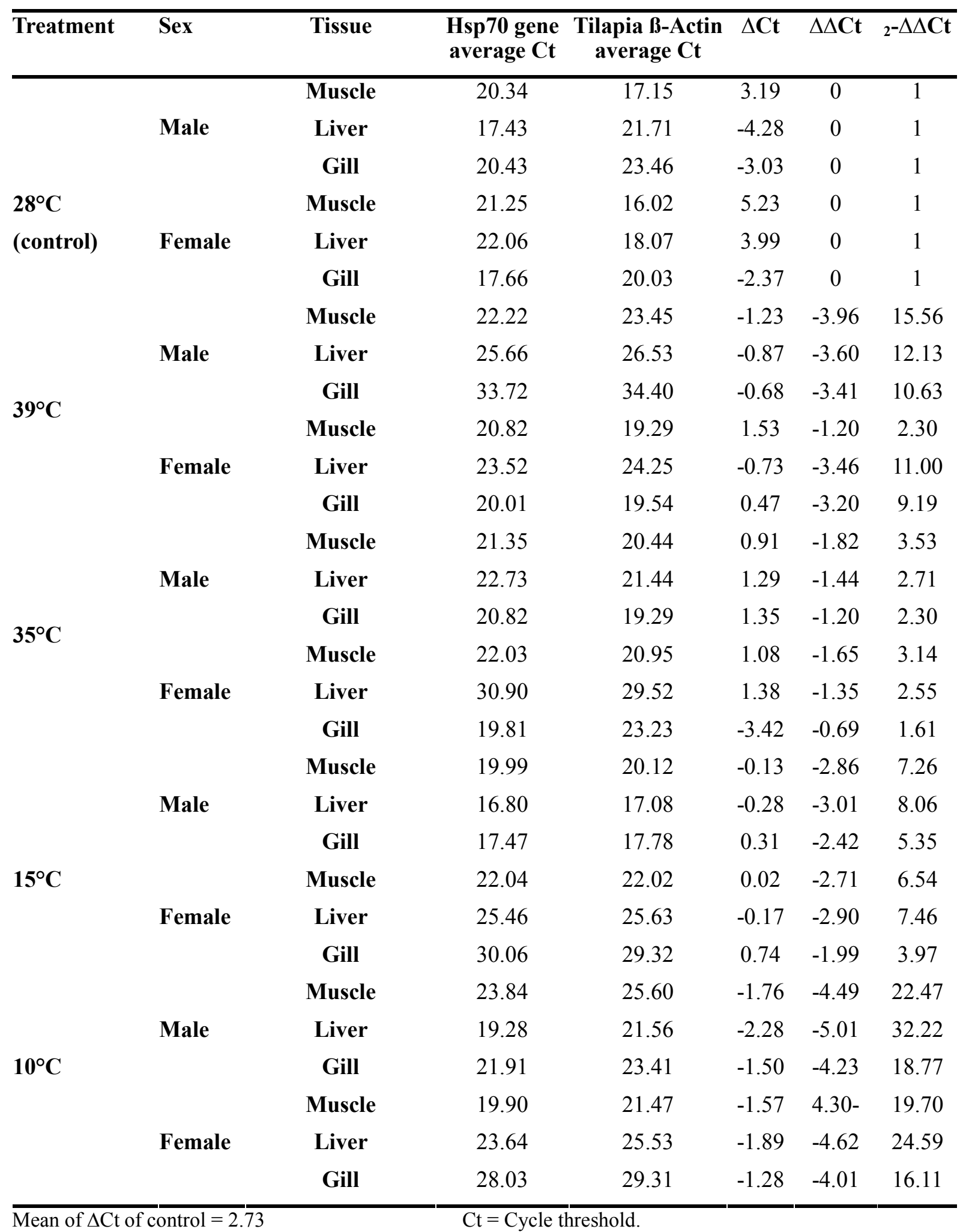

$\Delta \mathrm{Ct}=\mathrm{Ct}$ gene of interest-normalization factor. 


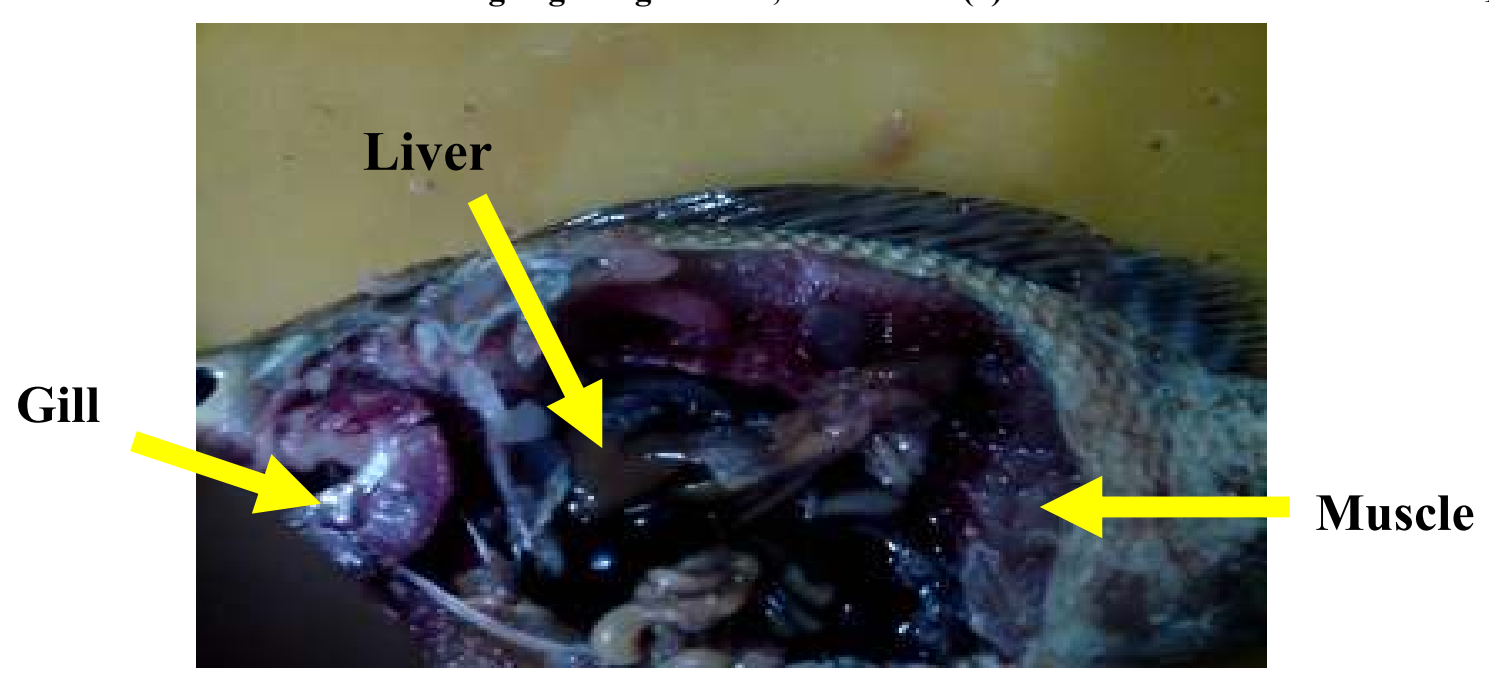

Fig. 1. Anatomy of Nile tilapia (Oreochromis niloticus); the three tissues of tilapia used in the present study

a

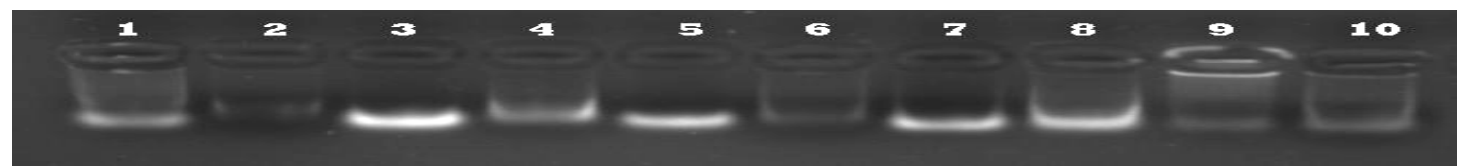

b

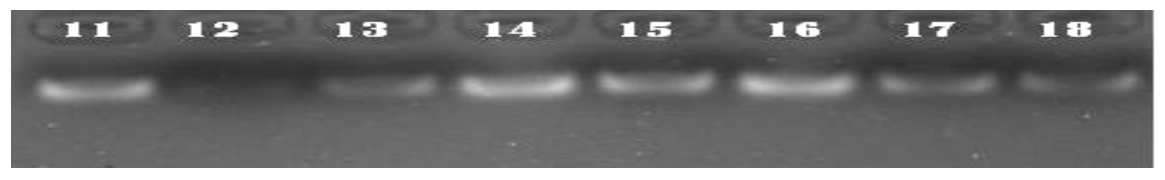

$\mathrm{c}$

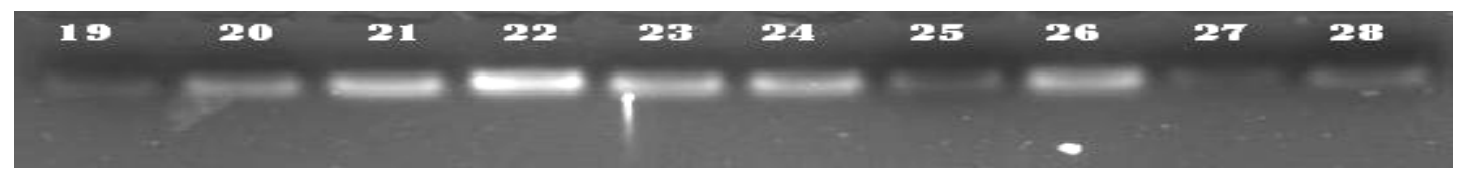

Fig. 2. RNA of Nile tilapia isolated from different tissues (a: muscle, b: liver and c: gill)

a

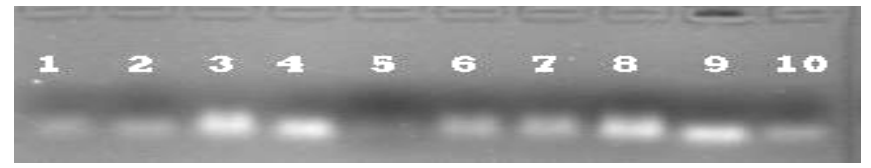

b

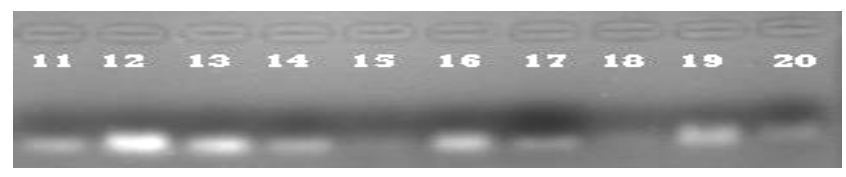

C

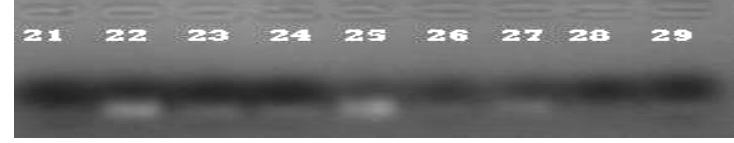

Fig. 3. Reverse transcriptase (cDNA) results for tilapia RNA extracted from different tissues (a: muscle, b: liver and c: gill) 


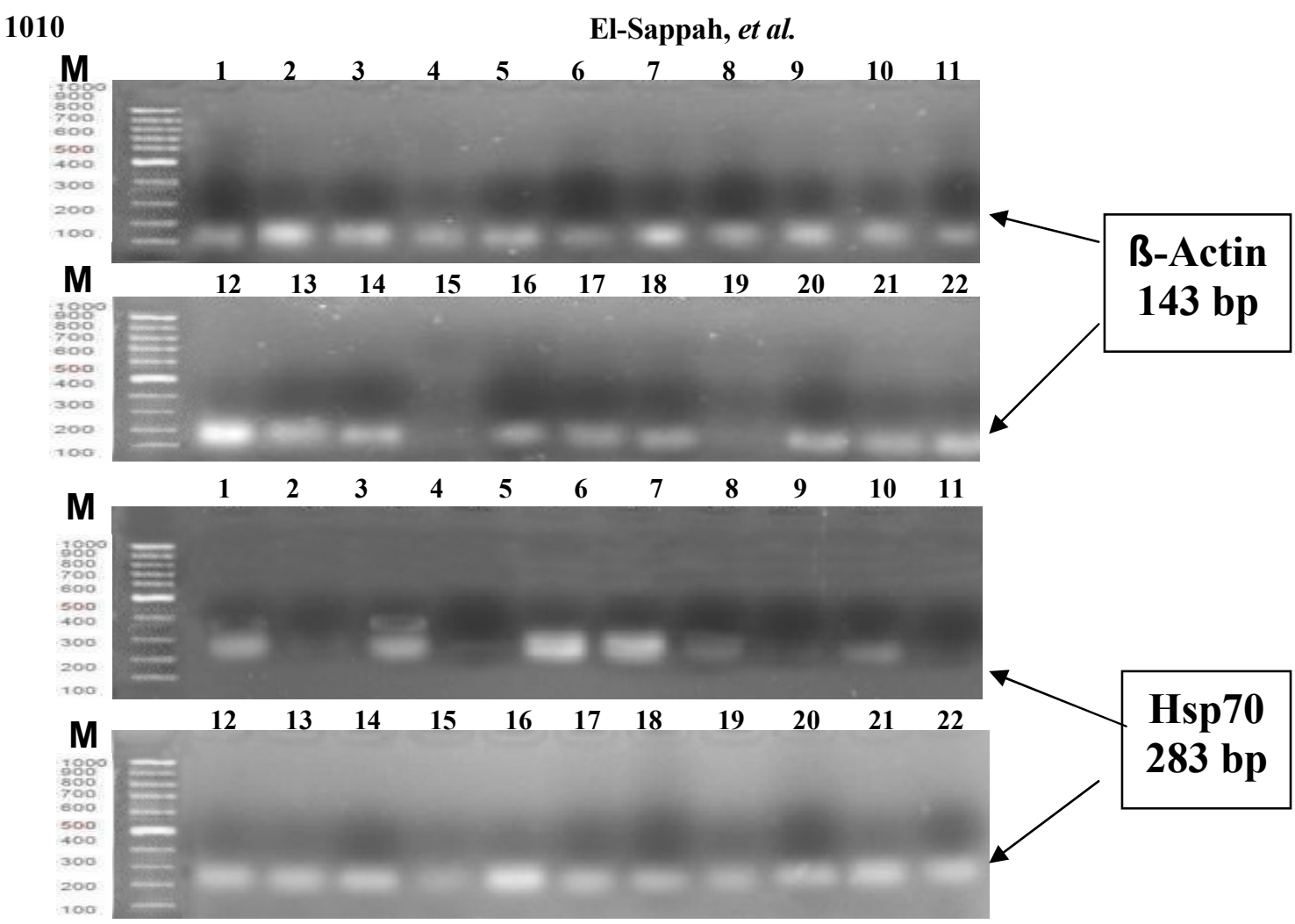

Fig. 4. Real-time PCR results for tilapia B-Actin and Hsp70 genes from different tissues (muscle (1-7), liver (8-15) and gills (16-22)

A)
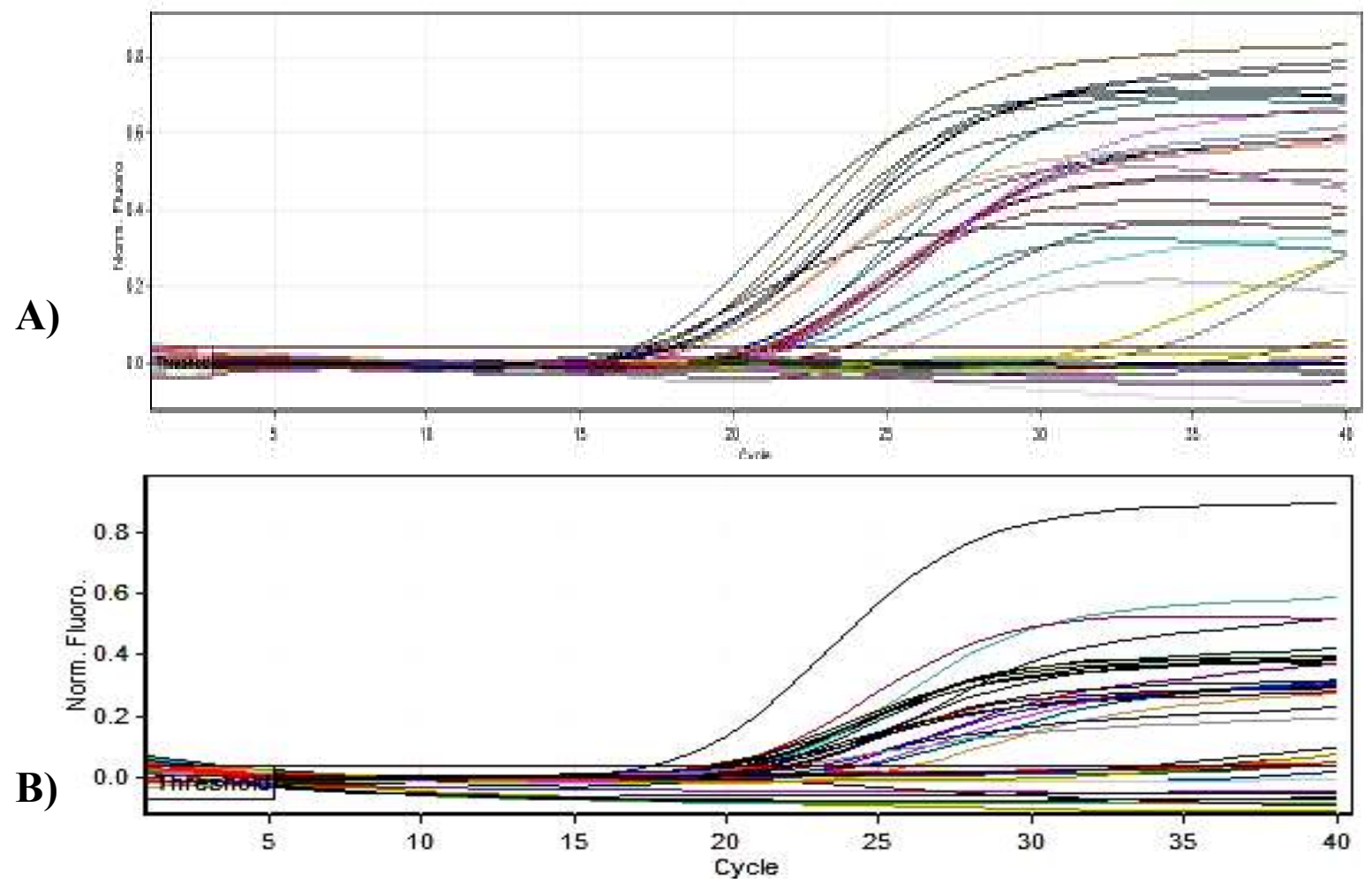

Fig. 5. Real-time PCR amplification plot for cDNA samples; A) after 2 hours, B) after 4 hr., treatment 


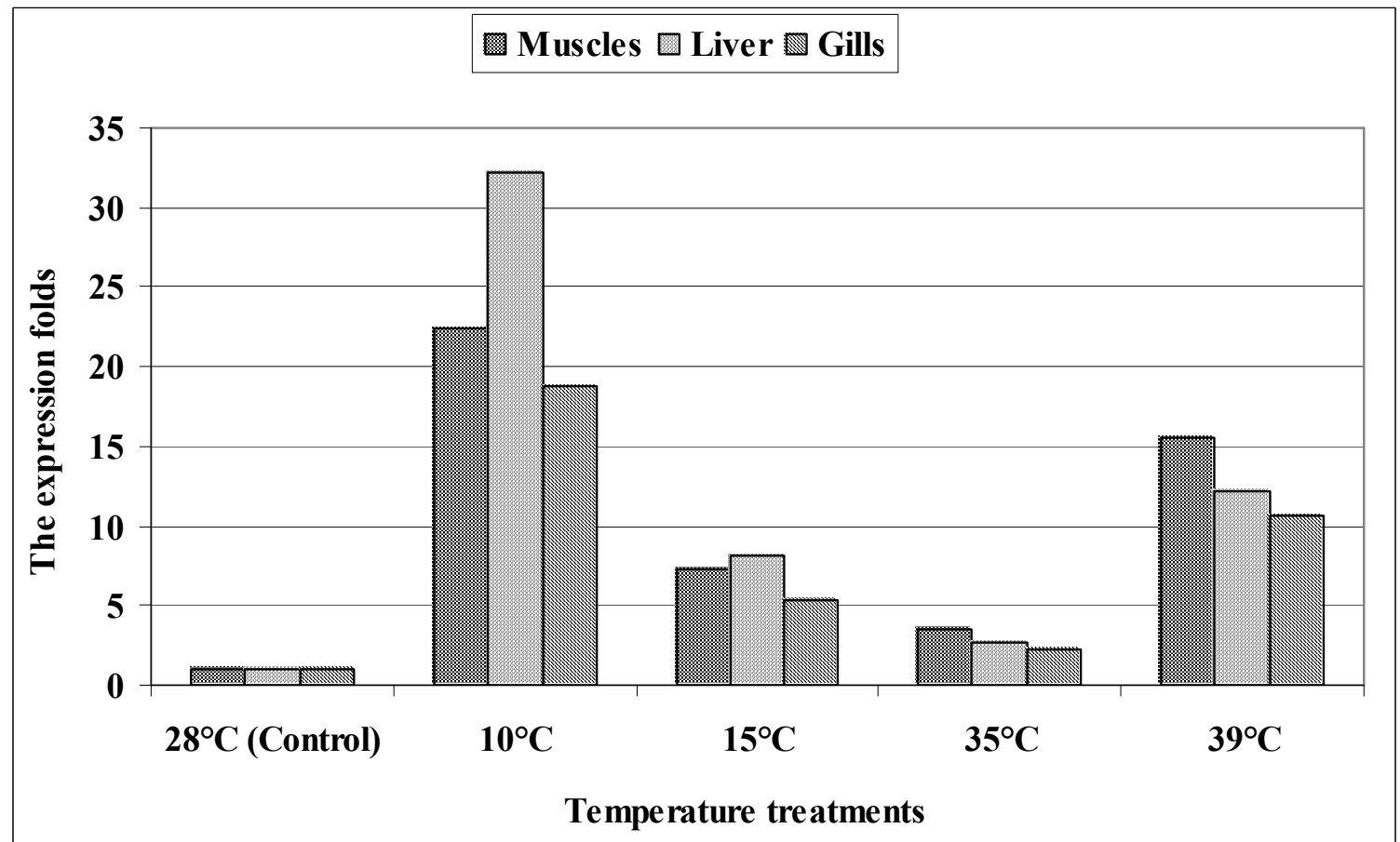

A)

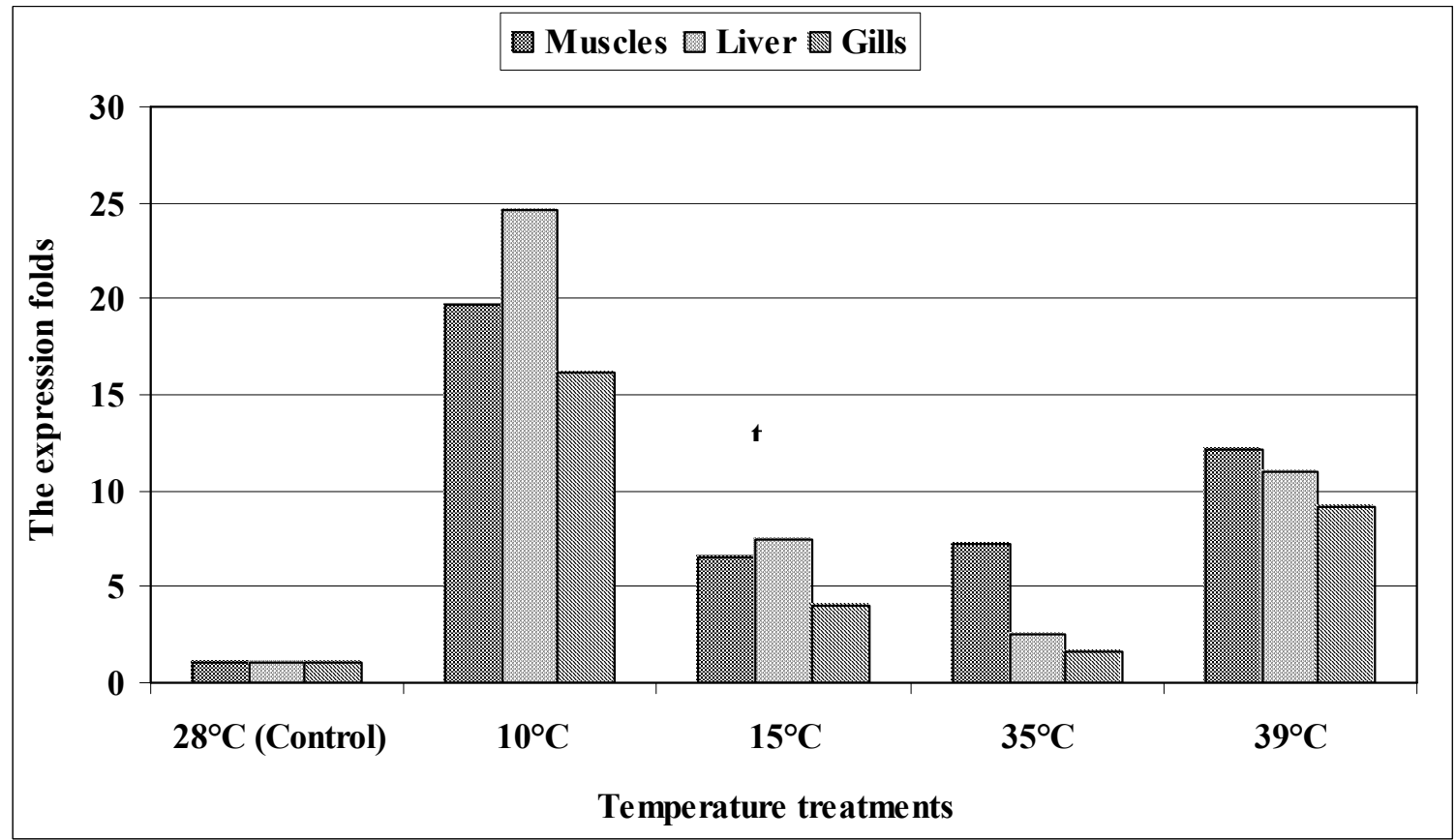

B)

Fig. 6. The expression chart of Hsp70 after 2 hours treatment in the three tissues (liver, gills and muscles) of Nile tilapia; A) in males, B) in females 


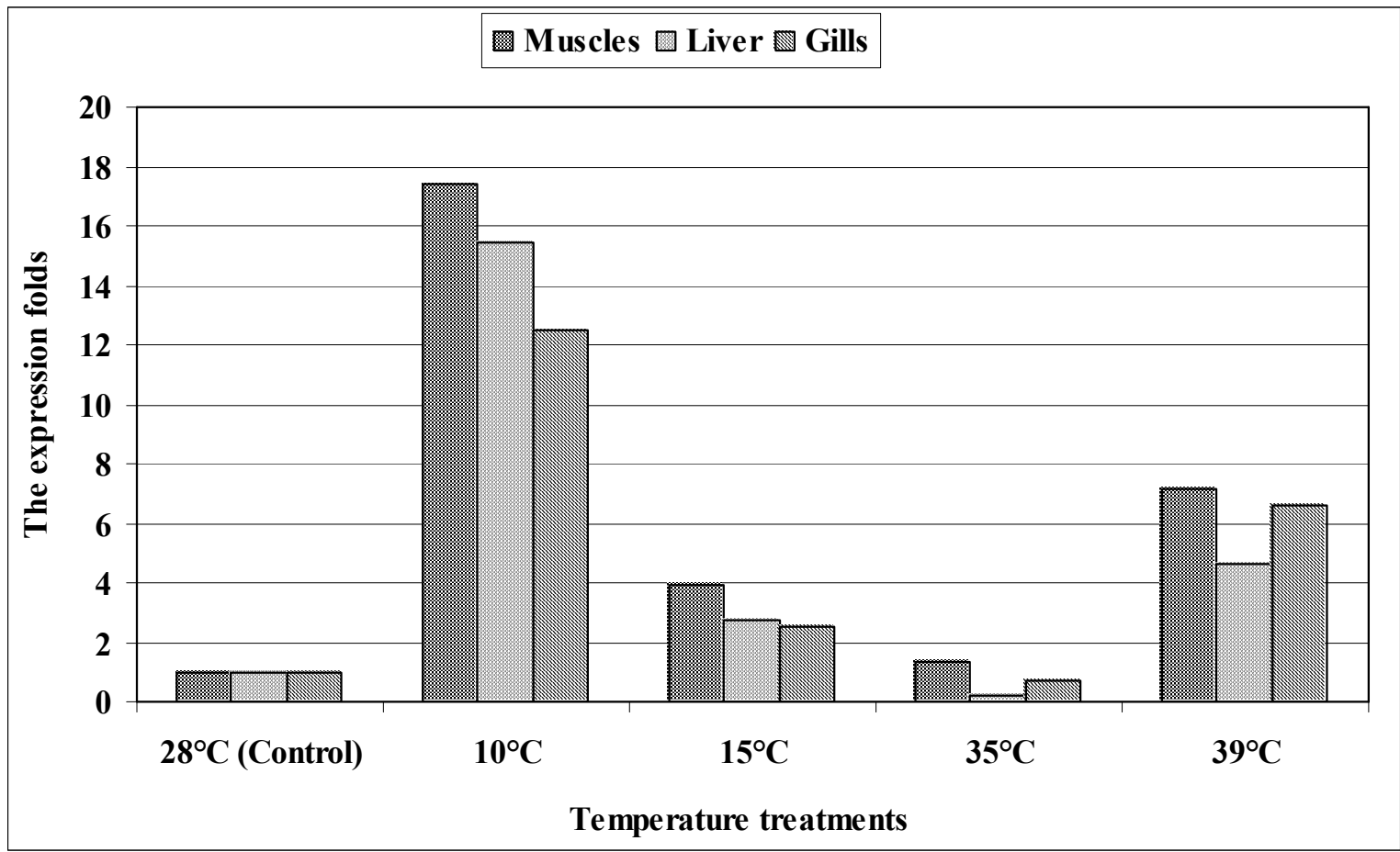

A)

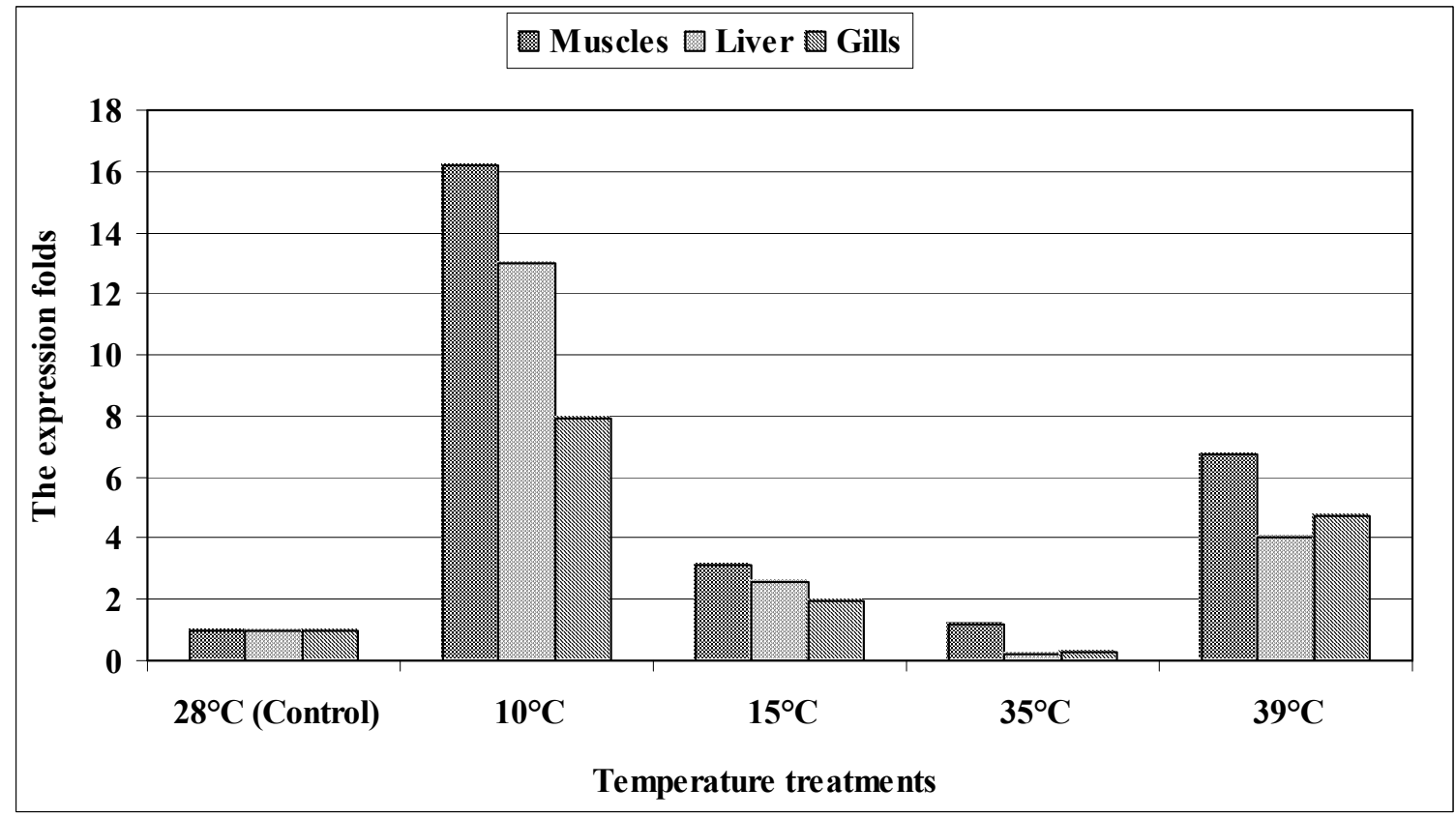

B)

Fig. 7. The expression chart of Hsp70 after 4 hours treatment in the three tissues (liver, gills and muscles) of Nile tilapia; A) in males, B) in females 
The effect of low as well as high temperatures on the histology of fish (Labeo boga), it can be concluded that lower temperature has been found to be more deleterious to liver compared to higher temperature (Rania et al., 2015). In heat shock treatments $\left(35^{\circ} \mathrm{C}\right.$ and $\left.39^{\circ} \mathrm{C}\right)$ in both tilapia sex, the most expressive tissues were muscle then liver and at last gills and this agree with Nichanan et al. (2009) where they estimated the expression of Hsp70 in Nile tilapia after shock treatments in different tissues and showed that the highest expression level of Hsp70 was found in kidney followed by muscle, liver and gill, respectively . Expression values of Hsp70 of male were more than female in all treatments, this mean that the male is the most tolerant and this agreed with that of Watanabe $e t$ al. (1985) whom reported that male tilapia tend to be larger than female and more tolerant also, Perschbacher and McGeachin (1988) found that tolerance to environmental condition as salinity of tilapia is affected by fish sex and size.

\section{REFERENCES}

Ballarine, J.D. and J.D. Hatton (1979). Tilapia: A Guide to their Biology and Culture in Africa. Stirling Univ., 174.

Basu, N., A.E. Todgham, P.A. Ackerman, M.R. Bibeau, K. Nakano, P.M. Schulte and G.K. Iwama (2002). Heat shock protein genes and their functional significance in fish. Gene, 295: 173-183.

Basu, N., C.J. Kennedy and G.K. Iwama (2003). The effect of stress on the association between Hsp70 and the glucocorticoid receptor in rainbow trout. Comparative Biochem. and Physiol., 134: 655-663.

Bukau, B. and A.L. Horwich (1998). The Hsp70 and Hsp60 chaperone machines. The Cell, 92: 351-366.

Caulton, M.S. (1982). Feeding, metabolism and growth of tilapias: some quantitative consideration. In: Pullin, RSV, LoweMcConnel, RH (Eds.). The Biology and Culture of tilapias. ICLARM, Manila, Philippines, 175-180.

Chen, J.D., F.H. Yew and G.C. Li (1988). Thermal adaptation and heat shock response of tilapia ovary cells. J. Cellular Physi., 134: 189-199.

Chervinski, J. and M. Lahav (1976). The effects of expossure to low temperature on fingerlings of local tilapa (Tilapia aurea) (Steindachner) and improted Tilapia (Tilapia vulcani) (Trewavas) and (Tilapia nilotica) (Linne) in Israel. Bamidgeh., 28: 25-29.

Chomczynski, P. and N. Sacchi (1987). Singlestep method of RNA isolation by acid guanidine thio-cyanate-phenol-chloroform extraction. Anal. Biochem., 162: 156-159.

Delaney, M.A. and P.H. Klesius (2004). Hypoxic conditions induce Hsp70 production in blood, brain and head Kidney of juvenile Nile tilapia Oreochromis niloticus. Agric., 236: 633-644.

Ergene, S. and T. Cavas (1999). Tiapia zillii (Gervais,1848) in (pisces: Cichlidae) Karyotype analysis. J. Inst. Sci. Tech. Gas. Univ., 12: 829-835.

Feder, M.E. and G.E. Hofmann (1999). Heatshock proteins, molecular chaperones, and the stress response: Evolutionary and ecological physiology. Annu. Rev. Physiol., 61: 243-282.

Feng, Q., A.N. Boone and M.M. Vijayan (2003). Copper impact on heat shock protein 70 expression and apoptosis in rainbow trout hepatocytes. Comp. Biochem. Physiol. Toxicol. Pharmacol., 135: 345-55.

Freeman, W.M., S. Walker and K.E. Vrana (1999). Quantitative RT-PCR: pitfalls and potentials. Bio. Techniques, 26: 112-125.

Gui-Cheng, S., D. Xiao-Hui, C. Gang, T. BiePing, Y. Qi-Hui, C. Shu-Yan and L. Hong$\mathrm{Yu}$ (2015). Physiological responses and Hsp70 mRNA expression of GIFT strain of Nile tilapia (Oreochromis niloticus) under cold stress. Agri. Res., 46: 658-668.

Hallare, A.V., H.R. Kohler and R. Triebskorn (2004). Developmental toxicity and stress protein responses in zebrafish embryos after exposure to diclofenac and its solvent, DMSO. Chemoshere, 56: 659-666. 
Hauser, W.J. (1977). Temperature requirement of tilapia. Calif. Fish Game 6: 228-233.

Herring, G., D.E. Gawlik and D.G. Rumblod (2009). Feather mercury concentration and physiological condition of great egret and white ibis nestling in the Florida Everglades. Sci. Total Environ., 407: 2641-2649.

Indhuleka, A. and G.P. Jeyanthi (2011). Analysis of experssion of heat-shock protein70 gene in salt stressed Groundnut (Arachis hypogaea L.) plants. Int. J. Pahrma and Biosci., 2 : 6275-6299

Iwama, G.K., P.T.Thomas, R.B. Forsyth and M.M. Vijayan (1998). Heat shock protein expression in fish. Rev. Fish Biol. Fish, 8: $35-56$.

Keller, J.M., F. Escara-Wilke and E.T. Keller (2008). Heat stress- iduced heat shock protein 70 expression is dependant on ERK activation in Zebra fish (Danio rerio). Cell Comparative Biotechnol. and Physiol., Part A., 150: 307-314.

Klein, D. (2002). Quantification using real time PCR technology: applications and limitations. Trends Mol. Med., 8: 257-260.

Koban, M., G. Graham and C.L. Prosser (1987). Induction of heat shock protein synthesis in teleost hepatocytes: effect of accumulation temperature. Physiol. Zool., 60: 290-296.

Langford, T.E. (1983). Electricity Generation and the ecology of water, Liverpool university, press. Liverpool. England.

Lindquist, S. and E.A. Craig (1988). The heatshock proteins. Annu. Rev. Genet., 22 : 631677.

Lindquist, S.L. (1986). The heat-shock response. Annu. Rev. Biochem., 55:1151-1191.

Liu, W. and D.A. Saint (2002). A new quantification method of real time reverse transcription polymerase chain reaction assay based on sim-ulation of polymerase chain reaction Kinetics. Anal. Biochem., 302: 5259.

Livak, K.J. and T.D. Schmittgen (2001). Analysis of relative gene expression data using real-time quantitative PCR and the 2$\Delta \Delta \mathrm{Ct}$ method. Methods, 25: 402-408

Luciana, D., L. Remigio, T. Patrizia, M. Alberta and C. Emilia (2006). Expression of stress proteins 70 in tilapia (Oreochromis mossambicus) during confinement and growing stress. Italian J. Zool., 42: 117-124.

Mayer, M.P. and B. Bukau (1998). Hsp70 chaperone systems: diversity of cellular functions and mechanisms of action. Biol. Chem., 37: 261-268.

Molina, A., F. Biemar, Lyengar A., Pruneta P. , Maclean N., Martial J.A. and Muller M. (2000). Cloning and expression analysis of an inducible Hsp70 gene from tilapia fish. FEBS Left, 47: 5-10.

Mosser, D.D., J. Van Oostrom and N.C. Bols (1987). Induction and de-cay of thermo tolerance in Rainbow trout fibro-blasts. J. Cellular Physi., 132: 155-160.

Multhoff, G. (2007). Heat shock protein70 (Hsp70) membrane location, export and immunological relevance. Methods, 43: 229237.

Nagy, A. (1987). Genetic manipulation on warm water fish in selection, hybridization, II, 112.

Nichanan, T., M. Chaichana, A. Dusit, P. Rungtawan and P. Saranya (2009). Preliminary study of heat shock protein gene expression in deferent tissues of Nile Tilapia (Oreochromis niloticus). 47 ${ }^{\text {th }}$ Kasetsart University Annual conference. Kasetsart, 148-155.

Park, H., I.Y. Ahn and H.E. Lee (2007). Expression of $\mathrm{Hsp} 70$ in the thermally stressed Antarctic clam laternula elliptica. Cell Stress and Chaperons, 12: 275-282.

Perschbacher, P.W. and R.B. McGeachin (1988). Salinity tolerance of red hybrid tilapia fry, juvenile and adults. In: Pullin, R.S.V., Bhukaswan, T., Tonguthai, K. and Maclean, J.L. (eds) Proc. ${ }^{\text {nd }}$ Int. Symposium on Tilapia in Aquac. ICLARM Conf. Proc., No. 15, Department of Fisheries, Thailand, and ICLARM, Manila, Philippines, 415-420. 
Radonic, A., S. Thulke, I.M. Mackay, O. Landot, E. Siegert and A. Nitsche (2004). Guideline to reference gene selection for Quantitative real time PCR Biochem. Biophys. Res. Commum., 313: 856-862

Rania, S., A. Sachar and K. Gupta (2015). Temperature fluctuations induced histopathological alterations in the liver of fish, Labeo boga i-nhabiting jammu waters. Int. J. Fisheries and Aquatic Studies, 2: 1216.

Sambrook, J. and M. Green (2002). Molecular Cloning: A Laboratory Manual, $4^{\text {th }}$ Ed. Cold Spring Harbor, New York

Sanders, B.M. (1993). Stress protein in aquatic organisms; An environmental perspective. Crit. Rev. Toxicol., 23:49-75.

Schelesinger, M.J. (1990). Heat shock proteins. J. Biol. Chem., 265: 1211-1214.

Schmittgen, T.D. and K.J. Livak (2008) Analyzing real-time PCR data by the comparative Ct method" Nature Protocols, 3: $1101-1108$.
Sharaf El-Deen, K.M. (2006). Accumulation of a $70 \mathrm{kda}$ stress protein in Nile Tilapia; Oreochromis niloticus, and as a biomarker of $\mathrm{Cu}$ exposure. Egypt. J. Aquat. Biol. and Fish, 2: 19-31.

Sorensen, J.G., T.N. Kristensen and V. Loeschcke (2003). The Evolutionary and ecological role of heat shock proteins. Ecol. Lett., 6: 1025-1037.

Trewavas, E. (1983). Tilapiine fishes of the genera Sarotherodon, Oreochromis and Danakilia. British Museun (Natural History) London, UK, 583.

Watanabe, W.O., C.M. Kuo and M.C. Huang (1985). Salinity resistance of Nile tilapia fry (Oreochromis niloticus) spawned and hatched at various salinities. Aquac., 48: $159-176$

White, C.N., L.E. Hightower and R.J. Schultz (1994). Variation of heat shock proteins among species of desert fish (Poeciliidani: Poeciliopsis). Molecular Biol. and Evol., 11: 106-119.

\section{تقدير تعبير الجين المسئول عن بروتين الصدمة الحرارية • vيلودالتون في أسماك البلطي النيلي باستخدام الـ PCR بـ الكمي

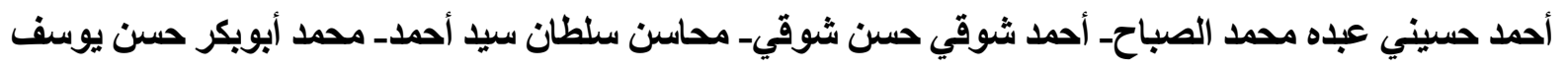

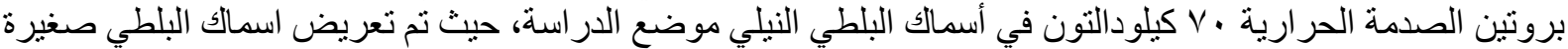

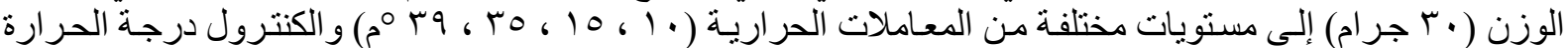

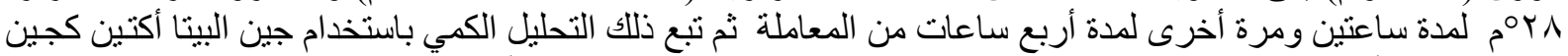

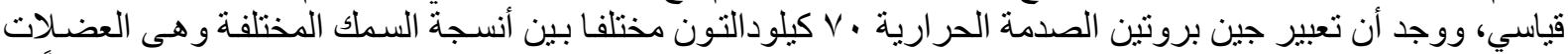

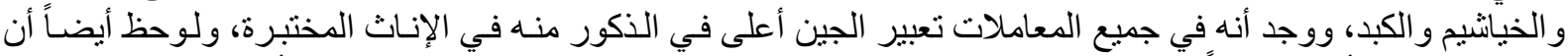

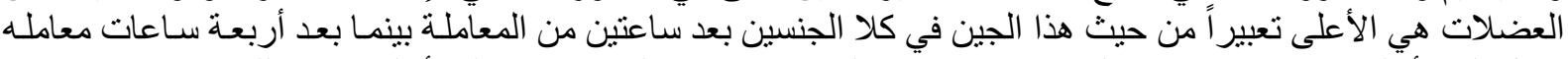 سجل الكبد أعلى مستوى من تعبير الجين في معاملات البرودة في حين العضلات سجلت أعلى تعبير اللجين تحت العبن معاملات

